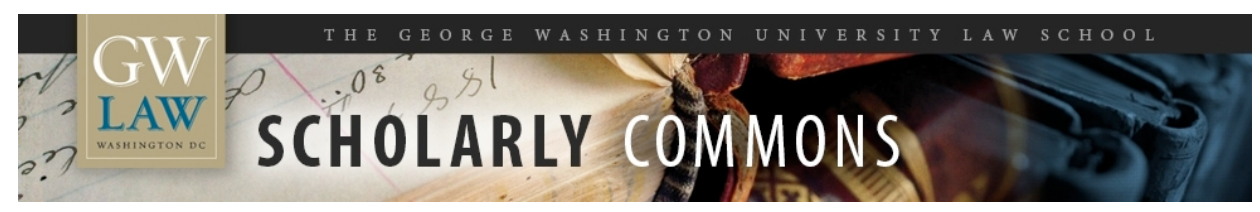

\title{
Docket Control and the Success of Constitutional Courts
}

\section{David Fontana}

George Washington University Law School, dfontana@law.gwu.edu

Follow this and additional works at: https://scholarship.law.gwu.edu/faculty_publications

Part of the Law Commons

\section{Recommended Citation}

David Fontana, Docket Control and the Success of Constitutional Courts in Comparative Constitutional Law, (Tom Ginsburg \& Rosalind Dixon, eds., Edward Elgar Publishing, 201)

This Article is brought to you for free and open access by the Faculty Scholarship at Scholarly Commons. It has been accepted for inclusion in GW Law Faculty Publications \& Other Works by an authorized administrator of Scholarly Commons. For more information, please contact spagel@law.gwu.edu. 


\title{
33. Docket control and the success of constitutional courts
}

\author{
David Fontana*
}

\section{INTRODUCTION}

In a chapter about comparative constitutional law, it might be surprising to start off this chapter with a mention of Alexander Bickel. Bickel was no doubt one of the landmark figures in American constitutional law. Writing in 1980, John Hart Ely called him 'probably the most creative constitutional theorist of the past twenty years'. ${ }^{1}$ But exporting some of Bickel's ideas about American constitutional law can actually inform our understandings of comparative constitutional law as well. Bickel's observation that the power of courts to do nothing - to avoid deciding constitutional cases entirely by declining to grant certiorari and hear a case in the first place - can greatly enhance the success of these courts, is an observation that can help us understand much of the success and failure of various courts deciding constitutional cases around the world, even beyond the United States Supreme Court. This judicial power to decide not to hear a case is a power that I will reference as the power of 'docket control'. It is not just a significant power for the United States Supreme Court, but for all courts deciding controversial constitutional cases.

There are many reasons why giving courts the power of docket control can contribute to their success. Deciding what cases to decide permits a court to issue the right decisions at the right times, what this chapter calls 'issue timing'. A court can avoid encountering an issue until the country is ready to discuss the issue, and perhaps ready to resolve the issue in the manner the court is contemplating - or the court can decide to avoid the issue altogether because the issue is too polarizing for the court to encounter. As part of this 'issue timing' is what this chapter calls 'legitimacy timing', meaning giving the court the power to decide what to decide allows courts both to initially create and then later maintain their legitimacy, even in situations when political forces might not support the specific outcome ordered by the court. Courts create and maintain their institutional legitimacy by giving political forces and the public time to adjust to a newer style of institution - a judicial institution - deciding leading issues of the day. But there is also a quantitative benefit to docket control, one related to legitimacy timing and the general politics surrounding courts. Giving courts docket control permits them to limit the sheer number of major issues they are deciding, which permits them to avoid excessive political fights, and gives them an agenda control power that allows them to compete on more equitable terms with the other branches of government, which do have agenda control.

Part of the argument of this chapter, then, is that courts deciding constitutional cases benefit from having the power to set their agenda - but also that docket control is an indispensable part of courts exercising this agenda-setting power. There are certainly other options that courts have at their disposal to enjoy some of the same agenda-setting powers that docket control gives courts. Indeed, these are some of the same options that Bickel mentioned. Courts 
can decide cases on technical grounds, as Bickel suggested. Courts can decide cases on substantive grounds, but do so narrowly, a position most famously associated in the United States with Cass Sunstein. ${ }^{2}$ There are many other options courts have to avoid deciding constitutional cases in a broad and controversial manner. ${ }^{3}$

Certainly, as this chapter will discuss, other courts deciding constitutional cases beyond just the United States Supreme Court have experimented with these options. But all of these other ways of giving courts agenda-setting powers share the same limitation: even though they involve courts in deciding constitutional issues in a less controversial fashion, they still involve courts in deciding constitutional issues. The power of docket control gives courts the power to avoid constitutional issues entirely, and the politics of that can often be better for courts.

This chapter should be considered an intellectual down payment on a larger project about the role that docket control plays in contributing to the success of constitutional courts. Because it is merely a down payment, and because of the structure of these chapters, my arguments will be mostly illustrative, drawing on helpful examples to highlight some of the dynamics that make docket control such a powerful contributor to the success of constitutional courts. Later work will make the same argument and probe these examples in greater detail, using more traditional large- and small-sample research design in different places.

For the purposes of this chapter, as well, I adopt an inclusive definition of the 'success' of constitutional courts - meaning the ability of the constitutional court to have their decisions enforced, their legitimacy respected and their political relevance ensured. As Ran Hirschl has noted, the 'success' of an element of a constitution can be hard to define, ${ }^{4}$ and more precise definition must await additional papers exploring docket control. Also for the purposes of this chapter, I will use the phrase 'constitutional review courts' to describe any high courts deciding constitutional cases. There are, of course, courts like the United States Supreme Court which decide constitutional as well as other cases, and courts like the German Federal Constitutional Court which exclusively decide constitutional cases - and this phrasing of "constitutional review courts' is meant to communicate some shared dynamics about the politics of constitutional review facing both generalist supreme courts and specialized constitutional courts.

\section{THE CURRENT REALITY OF DOCKET CONTROL}

With the proliferation in literature about comparative constitutional law, there is now much literature about differences in institutional design among many constitutional review courts. But, to this point, there is almost no literature about differences in docket control rules. This is a substantial part of the reason why the explanatory power of these differences in docket control rules has been neglected. As it turns out, even though the assumption is that constitutional courts have no control over their dockets and supreme courts do, many forms of constitutional review courts have substantial powers of docket control.

\subsection{A SCHOLARLY OVERSIGHT}

There is very little scholarship about docket control and constitutional review courts, along two dimensions, one factual, the other analytical. First, while there is much literature about the sorts of dimensions along which the structure of constitutional courts around the world 
vary, there is almost no discussion of variations in docket control as one of the dimensions of variation. The usual presentation of institutional variations focuses on a few topics. As Lee Epstein, Jack Knight and Olga Shvetsova have phrased it, courts differ in terms of (1) 'who has the power to engage in judicial review', ${ }^{5}(2)$ 'when can judicial review occur', ${ }^{6}$ (3) 'can judicial review take place in the absence of a real case or controversy', ${ }^{7}$ and (4) "who can initiate disputes' ${ }^{8}$ But there are additional - and, this chapter will argue, consequential differences - in the docket control process among courts, and scholars have not studied comprehensively the different docket control structures in place around the world. ${ }^{9}$ As an initial problem, then, there is simply very little aggregated information about the realities of docket control from which to draw conclusions..$^{10}$

Without this simple factual information available, then, it is unsurprising that the explanatory powers of docket control rules are ignored. Part of the reason for missing the analytical power of docket control differences is because the core question that institutional differences in docket control might help to answer - what makes constitutional courts succeed or fail is a question that scholars rarely ask in the first place. There is a substantial literature about the 'origins of dictatorship and democracy', ${ }^{11}$ the variables that might lead to the creation of democratic regimes. There is also a substantial literature on democratic failures, headlined by Juan Linz's contribution and the literature it spawned. ${ }^{12}$ When it comes to the rise and fall of constitutional courts, though, the literature is more asymmetrical. There are several different explanations for the creation of constitutional review courts, ${ }^{13}$ but very little literature about conditions under which the creation of constitutional courts leads to their eventual and durable success. This chapter offers an initial explanation as to part of the reason why constitutional review courts succeed, one deriving from institutional structure: the power of courts to decide what cases they hear in the first place can help create a politics of constitutional review that assists constitutional review courts.

\subsection{Docket Control as Common Institutional Practice}

The conventional wisdom, to the extent scholars have studied docket control, seems to be that supreme courts have broad discretionary jurisdiction and constitutional courts simply have 'no discretionary jurisdiction'. ${ }^{14}$ As Kim Lane Scheppele has written, the assumption is that 'constitutional courts do not typically have formally recognized discretionary powers to choose which cases they will decide'. ${ }^{15}$ Constitutional courts are supposed to be 'antiBickelian' ${ }^{16}$ in the very little power they have to 'do neither' and supreme courts are supposed to be Bickelian. The actual practice of the most successful constitutional review courts, regardless of their structure, is actually quite informed by Bickel's ideas of the importance of the power to decide not to decide.

It is certainly the case that in many countries with supreme courts, those supreme courts have broad powers over their docket. Since 1988 the Supreme Court of the United States has had almost complete control over what cases to hear on appeal. ${ }^{17}$ The Supreme Court of Canada heard 900 appeals over the past ten years, and less than 20 percent of those cases were heard as part of the Court's mandatory jurisdiction, with the rest subject to broad discretion by the Court in terms of what cases it wants to hear. ${ }^{18}$ The Supreme Court of India is granted, by the Constitution of India, control over what cases it can hear. ${ }^{19}$ The Supreme Court of Israel, particularly when heading petitions as the High Court of Justice (HCJ), has some discretion in deciding what cases fully to adjudicate and decide. ${ }^{20}$ 
Despite the conventional wisdom, though, constitutional courts in addition to supreme courts have broad control over the cases that they want to hear. Consider the German Federal Constitutional Court (FCC), the 'most active and powerful constitutional court in Europe'. ${ }^{21}$ The FCC can hear constitutional claims either by abstract review, concrete review, or by the filing of a constitutional complaint. Abstract review cases must be brought by specified members of the government. ${ }^{22}$ It is difficult for the FCC to avoid deciding these cases, but as a practical matter there have only been on average less than three a year brought to the FCC - and because of consolidation and other procedural details, the FCC has only decided about half of these abstract review cases. ${ }^{23}$

Concrete review cases are cases where a lower court not entrusted with jurisdiction over constitutional cases finds that there might be a constitutional problem in the course of addressing other legal claims. ${ }^{24}$ The FCC can decline to hear these cases because it only need hear these cases if the case presents major implications for lower courts and the FCC is convinced of the unconstitutionality of the action, rather than simply harboring doubts. ${ }^{25}$ The number of concrete review cases under Art. 100 (1) of the Basic Law is substantially lower than the number of constitutional complaints as well, so combined with the FCC's discretion not to hear these cases, they constitute a tiny part of the docket of the FCC. ${ }^{26}$ As an empirical matter, the overwhelming majority of cases are brought to the FCC as constitutional complaints - a full 96 percent of the caseload of the FCC, by one count. ${ }^{27}$ The FCC only grants review in less than 1 percent of the constitutional complaints it receives. ${ }^{28}$

The same institutional structure and constitutional review court docket control is true of many of the world's other constitutional courts. In Hungary, the very active and quite powerful constitutional court only decides a case as the whole court if a statute is being reviewed. ${ }^{29}$ If the challenge is to an administrative regulation, then the case is disposed of by a three-judge panel. $^{30}$ Because of this and other docket control rules, in its first three years the Constitutional Court of Hungary considered about 6000 petitions and only published between 200 and 300 decisions each year. ${ }^{31}$ In Brazil, much of the recent success of the court has been related to Constitutional Amendment 45, which permits the Supreme Federal Court to decline to hear a case if it does not present an issue of general importance. ${ }^{32}$

\section{WHY DOCKET CONTROL MATTERS}

\subsection{The Explanatory Power of Docket Control}

\subsubsection{The timing of constitutional review}

Part of the reason why having control over the cases that it hears can contribute to the success of constitutional review courts has to do with timing. Docket control permits a constitutional review court to address a constitutional issue when the timing is right for the court successfully to intervene to decide that issue - what I will hereinafter called 'issue timing'. Docket control also permits a constitutional review court to address a constitutional issue at a time and, as discussed later, at a pace - that allows the court to create and ensure its own legitimacy (what I will hereinafter call 'legitimacy timing'). As compared to other means of avoiding constitutional controversies, docket control leads to a political dynamic that better assists constitutional review courts. 
There are many reasons why a constitutional court might want to avoid deciding a particular constitutional issue altogether, or might want to avoid deciding a constitutional issue until the timing is right. We start with a simple statement: not all constitutional issues that constitutional review courts decide are created equal. A decision on the Dormant Commerce Clause in the United States, for instance, does not have the same salience - or the same judicial politics dynamic - as a case involving abortion. ${ }^{33}$ Some constitutional issues presented to courts might be so polarizing that a judicial decision on the issue could generate more political toxins, either forever or at a particular time, than the court could manage. By deciding a case, the constitutional review court would be taking sides on the issue, which would inflame passions on the losing side so much that it could lead to a dangerous political dynamic.

Not only would deciding a case related to the issue generate a firestorm from the losing side, but the nature of the debate between the competing sides might present a "clash of absolutes'. ${ }^{34}$ Therefore, not only would a judicial decision on the issue be viewed as incorrect by the losing side, but also it might be viewed as immoral or manifestly unjust. The other branches of government might also decide to avoid this polarizing issue for the same reasons that the constitutional review court does, which, as discussed later, would create problems for the constitutional review court if it does not have the identical power to avoid issues.

In the American system, a good example of the Supreme Court using its power of docket control to avoid entering a polarizing political debate entirely was its decision to deny certiorari to hear cases related to the constitutionality of the Vietnam War. ${ }^{35}$ The legitimacy - and therefore, in part - the constitutionality - of the Vietnam War was an intensely polarizing issue, ${ }^{36}$ but the Court never decided a case that directly addressed the constitutionality of the Vietnam War. ${ }^{37}$ If the American Supreme Court had in fact addressed the constitutionality of the Vietnam War, it would have survived, because of the support it enjoys. In countries where the constitutional review courts occupy a more precarious position, deciding a polarizing case at all, at any point in time, could lead to the destruction of the court. ${ }^{38}$

In other situations, courts avoid deciding a polarizing issue for some time, until the political timing is more conducive. Although Brown v Board of Education was intensely polarizing at the time it was decided by the United States Supreme Court, ${ }^{39}$ if a case like that had been presented to the Supreme Court and decided before then, the Supreme Court could have been seriously damaged. With not just an unsympathetic South and therefore part of Congress, but an unsympathetic President and all of Congress, who knows what might have happened if Brown had been decided years earlier. ${ }^{40}$

Other constitutional review courts that have experienced success likewise either avoided entirely or delayed deciding polarizing constitutional issues. In Israel, the Supreme Court of Israel has three roles, but in one of them it sits as the High Court of Justice (HCJ), with the power to decide what petitions fully to adjudicate. ${ }^{41}$ The Israeli Supreme Court decided explicitly as early as 1969 that judicial review of some sort was authorized, ${ }^{42}$ but it did not decide many major cases until years later. For years and years cases were brought to the HCJ questioning the legality of different military actions in the occupied territories - and for years and years the HCJ largely declined to decide these cases, with some exceptions. ${ }^{43}$ During this time, the HCJ tended to 'impose strict limitations on the ability of litigants to raise political issues in court' ${ }^{44}$

It was not until 1979 that the HCJ decided a number of major cases related to the occupied territories. ${ }^{45}$ Part of the reason for this had to do with the changing political climate in Israel, making the timing better for the HCJ just as it was for the American Supreme Court deciding 
Brown in 1954; and part of it was, as discussed later, because enough time had passed for the HCJ to establish a degree of core legitimacy ('legitimacy timing'). After these 1979 decisions, the HCJ issued other occasionally consequential decisions, but it was not until the 1990s when it started to issue many major decisions - and, by that time, the Israeli Supreme Court in general was wildly popular and seen as deeply legitimate, even while other branches of government (except the army) were not. ${ }^{46}$

More recently, many of the world's most successful constitutional review courts waited several years - until the politics of the situation had cooled off some - before deciding major cases related to the responses by the political branches to the events of September 11. The High Court of Australia issued its first major decision in 2007. ${ }^{47}$ The FCC in Germany declined to hear several cases, ${ }^{48}$ and did finally address a case related to the European Arrest Warrant in 2005. ${ }^{49}$ The House of Lords issued its first major decision in 2004. ${ }^{50}$ The Supreme Court of India issued its first major decision in 2004. ${ }^{51}$ The United States Supreme Court did not decide its first cases until it decided three of them in $2004 .^{52}$

Another reason why docket control can contribute to the success of constitutional review courts is a notion related to the idea of issue timing, what I will call 'legitimacy timing'. If issue timing is about the importance of the court deciding the right issue at the right time for the issue, then legitimacy timing is about the court deciding the right issue at the right time for the court. A constitutional review court might want to wait to decide an issue until the timing is right, and the timing might never be right. But the time must also be right for the court, and where the constitutional review court sits in the public and political dynamic of the country.

A preliminary concept must be addressed. Constitutional review courts might enjoy two different genres of support. One genre, 'specific support', refers to the support for a constitutional review court because of support for the particular decisions issued by that court. ${ }^{53}$ Another and more challenging form of support that constitutional review courts might benefit from is called 'diffuse support'. Diffuse support is 'a reservoir of favorable attitudes or good will that helps members to accept or tolerate outputs to which they are opposed or the effect of which they see as damaging to their wants' ${ }^{54}$ It is agreeing to disagree; the support that courts enjoy from members of the public or political figures who disagree with particular decisions but agree with the court's ability to make them, and therefore support the fundamentals of the constitutional review court even after that court issues a specific decision with which they disagree.

Most courts, even in established democracies, do not enjoy diffuse support in the eyes of most of the population. ${ }^{55}$ For most courts then - since most courts have to survive simply on specific support - deciding an issue that leads to any meaningful disagreement or political backlash can be dangerous. The mandatory portions of the dockets of the German FCC and the Supreme Court of Canada provide good examples. In Canada, although the docket of the Supreme Court is largely discretionary, ${ }^{56}$ the Supreme Court must hear reference cases brought to it by the political branches, unless there is some tangential jurisdictional issue. ${ }^{57}$ This has brought the established Canadian Supreme Court into political trouble when it had to deal with issues such as the Quebec Secession Reference. ${ }^{58}$ In then-West Germany, the FCC in its early years accepted very few cases involving meaningful constitutional disputes - indeed, of all of the cases filed it before it in 1955 using the constitutional complaint procedure, only one case was admitted and decided by the FCC. ${ }^{59}$ But then the FCC faced an abstract review challenge to German participation in some of the defense treaties of the new European government, ${ }^{60}$ a case that the FCC was of course obligated to decide. ${ }^{61}$ Ultimately, 
this situation might have helped the FCC, but in the short term it put the new FCC in a precarious position because it involved it in a major political battle of the day - and the FCC had no choice but to decide these cases. ${ }^{62}$

Particularly when the constitutional review court is new, and trying to transition from having simply specific support to enjoying a deeper legitimacy in the society, docket control is crucial. Early on during the existence of a constitutional court, political coalitions or the general public might not be ready for the constitutional court to decide cases. As a newer institution, the exercise of power by the court (even if it is just to decide the case on technical as opposed to substantive grounds) might seem alien to these political coalitions or citizens, and therefore more threatening. Moreover, it is often the case that the constitutional court might be staffed by judges tainted from their associations with previous autocratic regimes. ${ }^{63}$ It is not surprising, then, that courts that have been in operation for some time seem to be more popular than courts in operation for a shorter period of time, even controlling for other factors. ${ }^{64}$

At first, then, when the court is only supported if the outcomes of its decisions are supported, then the court can decide to hear cases that will not antagonize the public, perhaps even by focusing on lower salience issues to create a reservoir of support and trust from the public. Since a series of specific decisions that the public supports can lead to the creation of diffuse support and a stronger foundation of support for the court, ${ }^{65}$ over time the court can then grapple with more controversial and complicated issues as it builds diffuse support.

Many of the most successful constitutional courts have used this strategy, with great success. For one example of this strategy, consider the Constitutional Tribunal of Poland. The Tribunal started its operations in 1985, and was granted the power of judicial review in 1986. ${ }^{66}$ At first, the Tribunal functioned simply as an administrative court, reviewing what the executive could do by decree. ${ }^{67}$ The Tribunal simply policed the process of lawmaking, not the ultimate substantive acceptability of laws. Eventually, though, starting in 1989, the Tribunal started to review the substantive constitutionality of statutes. ${ }^{68}$ Many of the targets of its constitutional invalidations were the surely unpopular laws from the old Communist regime. ${ }^{69}$ Later, the Tribunal started to decide cases related to the major constitutional issues of the day. In 1991, for instance, the Polish Constitutional Tribunal invalidated an important pension reform statute. ${ }^{70}$

The more established Western constitutional courts adopted a similar strategy when the power of constitutional review was first established. Many forget that the United States Supreme Court was in operation for 14 years before it decided Marbury $v$ Madison, ${ }^{71}$ and it had three Chief Justices before it had John Marshall. During that time, the Court avoided major constitutional disputes. As William Michael Treanor put it, the 'Court upheld the one substantive congressional statute that it examined, and it did so even though there was a very strong argument that the statute ran afoul of constitutional text' ${ }^{72}$ The Court instead addressed the constitutionality of congressional statutes dealing with jurisdictional as opposed to substantive issues, and even then had very few cases of that sort. ${ }^{73}$ In France, it was thirteen years after the creation of the Constitution of the French Fifth Republic before the French Conseil Constitutionnel clearly stated that constitutional review was authorized by the French Constitution. ${ }^{74}$

\subsubsection{The quantity of constitutional review}

Part of legitimacy timing has to do not just with what cases are being decided and when, but 
how many cases are being decided. Deciding too many cases can be damaging to established and secure, as well as new and vulnerable, constitutional review courts. Constitutional review courts deciding many cases are creating many losing parties, meaning many political enemies and many political battles. In order to fight these battles, the court is at a severe disadvantage; deciding many cases will create political criticism that simply exceeds the available sources of political support that the court can use to fight back, and also is difficult for courts to handle because of the institutional disadvantages created by less discretionary agendas for courts and more discretionary agendas for political actors. In a system with a stable constitutional court, that might lead to a significantly weakened court; in a system with a fragile constitutional review court, this might lead to the elimination of the court altogether.

It should not be surprising, then, that many of the major constitutional review courts around the world fully decide just a small number of cases per year. The Supreme Court of the United States decides about 80 cases a year by full opinion, and less than half of these involve constitutional issues. ${ }^{75}$ The Supreme Court of Canada decided 74 cases last year. ${ }^{76}$ The Italian Constitutional Court decides about 500 cases per year. ${ }^{77}$ The French Conseil Constitutionnel decides about 100 cases per year. ${ }^{78}$ The Russian Constitutional Court decides about 211 cases per year. ${ }^{79}$ Part of the success of the newer constitutional review courts in Central and Eastern Europe is because they spent their earlier years deciding only about 50 or so cases. ${ }^{80}$

There is a very simple reason why permitting constitutional review courts to avoid deciding many cases helps them: quantity negatively correlates with quality. There is good reason, including some experimental evidence, ${ }^{81}$ to believe that reasoning affects the legitimacy of constitutional review courts, so more time might mean better reasoning and more legitimacy. The more cases a court has to decide, the less convincing its decisions will be, and it would simply be impossible for constitutional review courts to decide all or many of the cases they are faced with given the sheer number of those cases. Particularly with constitutional review courts first trying to establish themselves - and prove that they are legal as opposed to political bodies - quality legal reasoning might be important, and the sheer number of cases these courts face ${ }^{82}$ makes docket control therefore crucial.

But the politics of high volume constitutional courts might present an even bigger obstacle. The more cases that the court decides, the more enemies the court will be making, because the more parties the court will be ruling against. Many of these enemies might be politically inconsequential, or politically consequential but aggrieved about an issue of such low salience that these enemies can not use the court decision successfully to attack the court. In Hungary, for instance, the mostly successful Hungarian Constitutional Court decided many controversial cases in its earlier years. ${ }^{83}$ By 1995 , the Court had issued so many constitutional decisions that the number of political enemies conspiring against the Court had grown. The Court invalidated 26 provisions of an important law to reduce the economic impact of the Hungarian welfare state, and angered factions in the government attacked the Court for the first time. ${ }^{84}$

Not just are more enemies created to fight against, but with more cases decided, the political tools that courts can use to fight for their interests are reduced. Jeffrey Staton and Georg Vanbeg have written convincingly about how constitutional courts can use the power of publicity to convince other branches of government to comply with court decisions. ${ }^{85}$ Staton and Vanberg are writing mostly about constitutional review courts that are not in dire straits, ${ }^{86}$ where the support for courts is higher than for political institutions. In those situations, by 
drawing attention to court decisions, these courts compel the other branches to implement the decision because political actors do not want to ignore a public which both likes the constitutional court and is aware of what the constitutional court has said those other branches of government should do. Courts cannot equally publicize all decisions, and courts do not necessarily have many members of their staff. Courts can only issue so many press releases, ${ }^{87}$ write so many opinion essays, be interviewed on television so many times. If the constitutional review court is forced to decide many cases, that means that some of its decisions might be politically vulnerable because the court won't be available to take the political steps to protect those decisions.

Regardless of whether the constitutional court is popular or not, though, any court needs a 'support structure' to implement their decisions. ${ }^{88}$ After constitutional review courts issue decisions, there must be other actors in place to implement and enforce and support their decisions. Even after the constitutional review court issues its decision, for decisions not to be undermined there must be other groups who 'have coordinated research, facilitated the exchange of ideas and generated publicity around ... agendas' ${ }^{89}$ A constitutional review court issuing many decisions might simply overburden the support structure. This is particularly true in countries with smaller support structures, where the constitutional review courts might need the assistance of the support structures even more. For instance, in Costa Rica only 99 percent of citizens are involved in civil society activities, and in Colombia 8 percent - with the comparative number in the United States being a substantially larger 27 percent. ${ }^{90}$

Docket control can be crucial to constitutional review courts not only to help them fight political enemies effectively, but also to help them fight fairly. Legislatures and executives generally face few constitutional constraints on their agenda for a particular year. Constitutions include many negative restrictions on what the political branches are permitted to do. Even with the increasing spread of positive obligations that the political branches face, these obligations generally require minimal action on the part of the political branches and do not compel their agenda in any meaningful manner. Positive obligations might be vague. As Mark Tushnet has described it, they might be merely 'declaratory rights'.${ }^{91}$ The Constitution of Ireland mentions 'Directive Principles of State Policy', ${ }^{92}$ but states that these are simply 'intended for the general guidance of the [Parliament]' ${ }^{93}$ Constitutional rules providing simply 'general guidance' do not mean that the Parliament of Ireland has much in the way of a compelled agenda.

Sometimes these rights might be what Tushnet calls 'weak substantive rights' ${ }^{94}$ such as the command in the Constitution of South Africa that ' $[\mathrm{t}]$ he state must take reasonable legislative and other measures, within its available resources, to achieve the progressive realisation of this right'. ${ }^{95}$ Again, the political branches need not do much to comply with this obligation, and even if the government must act, often this can be delegated to administrative officials rather than something that must be addressed directly by the legislature or high-ranking executive officials. If positive obligations are more concrete, commanding a specific result (the Constitution of Mexico, for instance, guarantees that '[f]or every six days of work a worker must have at least one day of rest ${ }^{\prime 96}$ ), these might be self-executing and not require much time or effort on the part of the political branches.

The contrast with a constitutional review court with limited or no docket control should be clear. Even if political branches faced constitutionally compelled agendas, these agendas would be simply to focus on issues. By contrast, constitutional review courts can be compelled to focus on these issues, as well as or perhaps by focusing on specific petitions 
brought by individual parties. As a practical matter, of course, constitutions tend not to compel political branches to do anything in the first place.

Agendas are also not fixed - if a problem or a complaint is not solved by one branch of government, then it might need to be solved by another branch. It is often the case that political branches of government might manipulate the constitutional review courts to serve their own political agenda. One facet of this might be what Keith Whittington has observed, whereby judicial review is encouraged and furthered by political actors wanting to avoid controversial issues and therefore pass them on to courts. ${ }^{97}$ Another facet might be politicians using courts to gain attention for their own causes ${ }^{98}$ - but without having to resolve these causes through their own, singular, heroic but potentially risky political actions. Either way, if political actors can manipulate the agenda of courts, they might well do so; and this puts courts at a disadvantage if they do not have the capacity to control their agenda as well. In other words, then, if the design is to create some semblance of equity between the branches, docket control is a must.

\subsection{Imperfect Alternatives to Docket Control}

As mentioned earlier, there are certainly many tools that constitutional review courts have to avoid deciding entirely a polarizing issue, or to wait before deciding polarizing issues. ${ }^{99}$ But, even with those tools at its disposal, the power to decline to hear a case entirely occupies a special position. The decision not to hear a case can be more politically innocuous than deciding a case, but on secondary grounds. One reason is the 'clash of absolutes' logic described earlier. If any action related to these issues is highly consequential and morally tinged, then deciding a case, even on tangential grounds, could be more morally offensive and politically provoking than simply avoiding an issue altogether.

This is because, in many ways, deciding a case on tangential grounds is still deciding the case, while declining to hear the case altogether is practically and legally different. There are certainly many examples of constitutional review courts using tangential grounds to decide cases as a means of avoiding the core substantive issues. The Hungarian Constitutional Court in its first years decided its first abortion case on the grounds that the abortion rules were passed not through statute but through regulation. ${ }^{100}$ The Russian Constitutional Court ruled on the constitutionality of the war in Chechnya by looking at whether the rules and process leading to the commencement of wars were followed, not whether the actual war itself was constitutional. ${ }^{101}$ The sorts of concerns similar to the legitimacy timing concerns mentioned before surely played a part in the nature of these decisions - vague decisions or decisions ordering weak remedies pose less risk of non-compliance and therefore less of a threat to the legitimacy and power of the constitutional review court. ${ }^{102}$

While these are welcome tools for constitutional review courts to have at their disposal, having the power not to decide a case in the first place is also important - and different. If a constitutional review court decides to hear a case, there will be full briefing of the case, discussions of it in law schools and law journals, coverage of the case in newspapers, and debate about the issue among political figures. It is often only later that stakeholders know the constitutional review court will decide the case on tangential grounds, so all of the heat and intensity generated by the process leading to a substantive constitutional decision is generated by the process leading to a tangential decision. One study of the debates leading to decisions by the Israeli Supreme Court found ' $[t]$ he greatest portion of media coverage for 
political petitions does not refer to final court decisions but rather to earlier phases of the process: threats, the issuance of petitions, and most notably court proceedings while the petition is still pending'. ${ }^{103}$ By contrast, if the constitutional review court declines to hear the case in the first place, that whole process and publicity and attention is eliminated before it even starts.

In part because of this different amount of pre-decision attention, there is a different political dynamic following a decision not to hear a case as compared to a decision on a tangential ground. Decisions by constitutional review courts not to decide cases rarely generate newspaper attention, and rarely generate political attention. ${ }^{104}$ By contrast, decisions about major constitutional cases can generate much attention. When the HCJ in Israel decided their first series of major cases related to the occupied territories, one of the major newspapers printed these decisions verbatim over four pages in the newspaper. ${ }^{105}$

In this way, decisions not to hear a case impose no direct political costs on constitutional review courts, since they are decisions made with no attention, and therefore little oversight or accountability. The constitutional system - more generally and longitudinally - might suffer by the incoherence and lack of clarity that results from inaction by the highest constitutional review court in a country. The constitutional review court might suffer gradually, systematically from these results. But these costs are more diffuse and gradual. By contrast, decisions by constitutional review courts to decide a case on tangential grounds generate more attention and more immediate and tangible risk. If the HCJ had decided a case related to the occupied territories in any way, regardless of how technical, it would have made frontpage news. A decision not to decide receives far less attention.

\subsection{The Dangers of Docket Control}

The sorts of powers and opportunities for success presented by docket control discussed above also carry with them some obvious dangers. Deciding when to decide might be an action constrained very little by law, and controlled very much by political judgment. This is precisely the sort of judgment that constitutional review court judges might have in low amounts, while the actors they are competing against have it in greater amounts. The danger, then, created by docket control is the danger created by granting a more overtly political power to a formally legal branch of government.

But this danger is not merely theoretical. There are several examples of constitutional review courts miscalculating in their use of their docket control, and paying a severe price for it. The early failures of the Constitutional Court of Russia after the dissolution of the Soviet Union are a good example of this. In December 1991, the new Court went into operation, with Valery Zorkin as the Chairman of the Constitutional Court. ${ }^{106}$ The Court had enormous discretion about what cases to hear. It received about 1700 complaints in its first year. ${ }^{107}$ Most of the complaints were rejected by the Registry of the Court, but a small number went forward and were submitted to one of the specialized divisions of the Constitutional Court. ${ }^{108}$ These specialized divisions would then prepare a report, the Court would deliberate about this report and decide whether to move forward with the case based on this report, and if it did decide to go forward, Zorkin would assign the case to a particular Justice to lead the Court's discussion and decision on the case. ${ }^{1099}$

In less than two years, the Zorkin Court used this discretion to issue 20 decisions invalidating exercises of executive or legislative powers, including cases involving controversial 
issues related to banning the former Communist Party or taking over media outlets. ${ }^{110}$ At the same time, the Court did little to decide cases that would receive broad and cross-cutting support from the public. It decided very few cases related to human rights, deciding only six cases on these issues in its first 16 months. ${ }^{111}$ Most members of the Court insisted that the Court focus on the political crisis between the new President Boris Yeltsin and the Duma and not on the human rights concerns faced by average citizens. ${ }^{112}$ It should not be surprising, then, that a poll in January 1993 found a meager 10 percent of the population trusted the Russian Constitutional Court - while 23 percent trusted the President. ${ }^{113}$

Eventually, then, this Court was abolished. ${ }^{114}$ The Court that was created to replace it eliminated much of the docket control that the previous Court had enjoyed. The previous Court could reject a petition if it considered review of the case 'inadvisable'; 115 the new Court seems to have fewer screening standards. ${ }^{116}$ Even under the new regime, though, the Russian Constitutional Court does not have to fully adjudicate all cases brought to it. Between 1994 and 1999, the Court received about 15,000 petitions, and about 98 percent were dismissed by the Secretariat of the Court. ${ }^{117}$ That left 300 cases brought to the full Court, and the Court decided only 39 of those fully on the merits. ${ }^{118}$

While there are reasons to believe that constitutional review courts will constantly make mistakes in their use of docket control, there are also reasons to believe these mistakes are not fundamental or crucial. Constitutional review court judges do not come from purely legal backgrounds. Constitutional review court judges in all sorts of constitutional democracies are appointed by political officials. In the United States, Supreme Court Justices are appointed by the President with the advice and consent of the Senate. ${ }^{119}$ In France, the members of the Conseil Constitutionnel are appointed one-third by the President, one-third by the President of the National Assembly and one-third by the President of the Senate. ${ }^{120}$ The basic logic is essentially the same across all constitutional democracies: the appointing individuals are elected, and so the judges they appoint are likely to be tied to, and not entirely unaware of, the political process. However technical appointment and promotion might be in some lower courts in some countries, appointments to constitutional review courts are almost always political in part.

After their appointments, constitutional review courts are not entirely unaware of the political situation surrounding the constitutional issues presented to their courts. Constitutional review courts are facing thousands upon thousands of petitions every year. The Supreme Court of the United States receives about 7000 petitions per year. ${ }^{121}$ In Argentina, the Supreme Court receives 26,000 petitions per year. The Supreme Federal Court in Brazil in 2001 had 110,771 petitions filed before it. ${ }^{122}$ These petitions - the stories they present, the lower court decisions they embody - serve as information to the constitutional review court about how different constitutional issues are faring in the general public, and in the political system. Constitutional review does not just generate outcomes, it provides information to constitutional review courts. ${ }^{123}$

Of course, there were concerns voiced in response to Bickel's initial articulation of the benefits of docket control decades ago. These concerns were largely normative in a theoretical as opposed to an actual way. Gerald Gunther, in his famous response to Bickel's arguments, criticized Bickel for his lack of devotion to principle. ${ }^{124}$ Beyond that, according to Gunther, by declining to hear cases, the Supreme Court was not offering reasons in the first place, so there was very little candor about what was transpiring. ${ }^{125}$ Gunther's concerns are conceptually valid, but as mentioned before, denials of cases receive virtually no public or 
political attention. The reality, then, of a political actor or the public finding the lack of principle or lack of candor troubling are quite slim.

There might also be a concern that empowering constitutional review courts to avoid constitutional cases will lead to even more 'underenforced constitutional norms' ${ }^{126}$ than is necessary. Indeed, the underenforcement of constitutional rights by constitutional review courts can weaken these courts sometimes just as much as the overenforcement of rights can. ${ }^{127}$ I will have more to say about this in other writings on docket control, but for now it is worth noting that this is part of the reason that other courts have taken up the cause of protecting constitutional rights. In the years before the Canadian Supreme Court intervened in issues related to September 11 - and indeed even since then - the lower courts have issued many decisions protecting constitutional rights. ${ }^{128}$ The same has become true even in countries where only constitutional courts are supposed to protect constitutional rights, but other courts have found ways to issue decisions that have the same effects of protecting constitutional rights. These decisions all exist outside of the major national politics that both precedes and follows decisions of the highest constitutional review courts.

\section{CONCLUSION}

The burgeoning literature on comparative constitutional law has led to a burgeoning literature on constitutional design. The institutional structures put in place in constitutions, according to this emerging area of scholarship, might play a substantial role in the later emergence of this constitutional order. The predictable elements of constitutional design have been studied at length: whether to create presidential, parliamentary or semi-presidential regimes; the terms of constitutional court judges; and so on.

But, at the end of the day, no institutional structure turns out to be more important for the judicial branch created by a constitution than the control given by that constitution and related documents to the courts created. It is almost universal for political actors to receive control not just over the decisions they make, but of the issues they decide to focus on in the first place. Likewise, giving courts - particularly constitutional review courts - the ability to decide what to decide proves crucial to the success of these courts. A court empowered to set its agenda is a court that can avoid excessive political conflict and ensure maximum compliance. For new courts and old courts alike, then, there is no issue more important than an issue that appears to be the most simple: the content and structure of the docket of the court.

\section{NOTES}

* For comments on this chapter, my thanks to Rosalind Dixon, Tom Ginsburg, Daphne Barak-Erez, Barry Friedman, Chip Lupu, Micah Schwartzman, Kim Lane Scheppele, Brad Snyder, Amanda Tyler and David Zaring.

1. Hart Ely, John. Democracy and Distrust: A Theory of Judicial Review (1980) at 71. See also Schmidt, Benno. History of the Supreme Court of the United States: The Judiciary and Responsible Government 1910-21, Part 2 (1984) at 722 (labeling Bickel as 'the most brilliant and influential constitutional scholar of the generation that came of age during the era of the Warren Court').

2. See Sunstein, Cass R. One Case at A Time: Judicial Minimalism on the Supreme Court (1999); Sunstein, Cass R. 'The Supreme Court, 1995 Term - Foreword: Leaving Things Undecided', 110 Harvard Law Review 4 (1996) 
3. See Katyal, Neal. 'Judges as Advicegivers', 50 Stanford Law Review 1709-22 (1998) (summarizing different options courts have at their disposal).

4. See Hirschl, Ran, 'The "Design Sciences" and Constitutional "Success", 87 Texas Law Review 1353-72 (2009).

5. Epstein, Lee, Jack Knight and Olga Shvetsova, 'The Role of Constitutional Courts in the Establishment and Maintenance of Democratic System of Government', 35 Law \& Society Review 117, 121 table 1 (2001) (discussing which courts have the power to exercise constitutional review, and contrasting the diffuse American system with the concentrated European system).

6. Id. (contrasting the American system, where constitutional review takes place after a law goes into effect and the European system, where courts have that power as well as the power to review laws before they go into effect).

7. Id. (contrasting American standing rules with the more tolerant abstract review culture of European courts).

8. Id. (contrasting American rules limiting lawsuits to parties with standing to more tolerant and permissive European rules). For additional institutional features that have been discussed - and contrasted between countries - see, for instance, Horowitz, Donald L. 'Constitutional Courts: Primer for Decision Makers', 17(4) Journal of Democracy 125, 128 (2006) (listing the same institutional features, but also referencing variations in judicial appointment and tenure and the effects and reversibility of judicial decisions), Tushnet, Mark. 'Marbury $v$ Madison Around the World', 71 Tennessee Law Review 251, 252-7 (2004) (listing the same institutional features, and adding variations in judicial independence).

9. The information available in academic articles is generally presented as an informational afterthought, rather than as a key institutional feature relevant for analytical purposes. See, e.g., Scheppele, Kim Lane. 'Guardians of the Constitution: Constitutional Court Presidents and the Struggle for the Rule of Law in Post-Soviet Europe', 154 University of Pennsylvania Law Review 1757, 1769 n. 29 (2006) (describing docket-control style procedures in Russia and Hungary).

10. Part of the reason for the dearth of information is because even though the power to decide which cases to hear is enormously important, and seems to be a decision of constitutional-level importance, it is often a decision reflected not in constitutional text but rather in statutory text. See, e.g., Heun, Werner. 'Access to the German Federal Constitutional Court', in Constitutional Courts in Comparison: The US Supreme Court and the German Federal Constitutional Court, edited by Ralf Rogowski and Thomas Gawron, 125-57 (2002) (describing statutory changes affecting the docket control of the German Federal Constitutional Court). And however difficult it is to do comparative constitutional research, comparative statutory research might be even more difficult.

11. See Moore, Barrington. Social Origins of Dictatorship and Democracy: Lord and Peasant in the Making of the Modern World (1965).

12. For Linz's arguments, see Linz, Juan J. 'Presidential or Parliamentary Democracy: Does It Make a Difference?', in The Failure of Presidential Democracy: Comparative Perspectives, edited by Juan J. Linz and Arturo Valenzuela, 5-44 (1994). For some notable responses to Linz, see Przeworski, Adam, Michael E. Alvarez, José Antonio Cheibub and Fernando Limongi. Democracy and Development: Political Institutions and Well-Being in the World, 1950-1990, at 50-51 (2000); Stepan, Alfred and Cindy Skach 'Constitutional Frameworks and Democratic Consolidation', 46 World Policy 1 (1993) (gathering data to contrast pure presidentialism with pure parliamentarism in Latin American and Eastern European countries).

13. For the major arguments, see Ginsburg, Tom. Judicial Review in New Democracies (2003); Hirschl, Ran. Towards Juristocracy: The Origins and Consequences of the New Constitutionalism (2007).

14. Comella, Victor Ferreres. 'The Consequences of Centralizing Constitutional Review in a Special Court: Some Thoughts on Judicial Activism', 82 Texas Law Review 1705, 1713 (2004).

15. Scheppele, Kim Lane. 'A Comparative View of the Chief Justice's Role: Constitutional Court Presidents and the Struggle for the Rule of Law in Post-Soviet Europe', 154 University of Pennsylvania Law Review 1757, 1769 (2006).

16. Comella, supra note 14 , at 1713 .

17. See Judiciary Act of 1925 (43 Stat. 936). It was only after changes in 1988 that the Supreme Court could decline to hear appeals from state supreme courts challenging the constitutional acceptability of state statutes. See 42 USC $\$ \S 1252,1254(2)$ (repealed 1988).

18. See Supreme Court of Canada, Bulletin of Proceeding: Special Edition (2009).

19. India Constitution, Art. 132 (stating that the High Court must 'certify that the case involves a substantial question of law as to the interpretation of this Constitution' before the Supreme Court will accept the case for review). See also India Constitution, Art. 133(a) (stating that in civil cases there must be a 'substantial question of law of general importance'); Art. 133(b) (stating that in civil cases it must be 'in the opinion of the High Court [that] the said question needs to be decided by the Supreme Court').

20. Yoav Dotan has explained the process:

A petition to the HCJ can be written by the layman, and at no stage of the proceedings is representation by a lawyer required. Any person who has reason to believe that a particular public agency denies her legal 
rights may petition the Court and apply for an order nisi. A single judge reviews the petition. The judge may order a preliminary hearing before three justices to take place, requesting the respondent to supply the Court with a concise statement as to the reasons and background for the relevant government action. Alternatively, the judge may order an issue nisi, requiring the respondent to appear in court and show why a particular action should or should not be performed. A full hearing before three judges would then be held before the Court reaches its full decision.

Dotan, Yoan. 'Judicial Rhetoric, Government Lawyers, and Human Rights: The Case of the Israeli High Court of Justice During the Intifada', 33(2) Law and Society Review 319, 323 (1999).

21. Kommers, David. 'The Federal Constitutional Court in the German Political System', 26 Comparative Political Studies 470, 470 (1994).

22. German Basic Law, Art. 93(1).

23. See Landfried, Cristine. 'Judicial Policy-Making in Germany: The Federal Constitutional Court', 15 Western European Policy 50, 51 (1992).

24. German Basic Law, Art. 100(1).

25. See, e.g., Heun, supra note 10 at 128 .

26. Abstract and concrete review combined make up $2.03 \%$ of FCC cases, http://www.bundesverfassungsgericht. de/organisation/gb2008/A-I-1.html

27. Cases September 7, 1951-December 31, 2008, available at http://www.bundesverfassungsgericht.de/ organisation/gb2008/A-I-1.html

28. See Kommers, Donald P. The Constitutional Jurisprudence of the Federal Republic of Germany 23 (2nd edition, 1997).

29. Scheppele, supra note 9 , at 1770 n. 29.

30. Id.

31. Id. at 1780. See also id. at 1785 (noting that the Constitutional Court issued 1871 decisions in its first nine years).

32. See De Santa Cruz Oliveira, Angela Jardim. 'Reforming the Brazilian Supreme Federal Court: A Comparative Approach', 5 Washington University Global Studies Law Review 99, 100 (2006).

33. See, e.g., J. Mitchell Pickerill, Constitutional Deliberation in Congress: The Impact of Judicial Review in a Separated System, 67 (2004) (discussing the different politics of high versus low salience constitutional issues).

34. See, e.g., Laurence H. Tribe, Abortion: The Clash of Absolutes (1992) (discussing the uncompromising and absolute language used by those involved in the constitutional debate over abortion).

35. See, e.g., Mora v McNamara, 387 F.3d 862 (DC Cir. 1967), cert. denied, 389 US 934 (1967); Orlando v Laird, 443 F.2d 1039, 1043-4 (2d Cir. 1971), cert. denied, 404 US 869 (1971).

36. See, e.g., King, Michael. 'Assimilation and Contrast of Presidential Candidates' Issue Positions', 41 Public Opinion Quarterly 515 (1977)

37. The Supreme Court did decide First Amendment and other cases related to the Vietnam War, but nothing related to the core, polarizing issue about the War's legitimacy. See, e.g., Greer v Spock, 424 US 828, 838 (1976) (deciding about speech rights on military base); Cohen v California, 403 US 15, 26 (1971) (upholding First Amendment rights of protester who put words 'Fuck the Draft' on the back of his jacket).

38. In later papers about the importance of docket control, I will expand in greater detail and therefore be more exacting about the relationship between the precise status and success of the court and its precise docket control rules.

39. See, e.g., Klarman, Michael J. 'The Puzzling Resistance to Political Process Theory', 77 Virginia Law Review 747, 817 n.309 (1991) (noting that support for school integration hovered below 50 percent).

40. See, e.g., Justice Douglas memorandum (January 25, 1960), reprinted in Melvin I. Urofsky, The Douglas Letters 169 (1987) (noting Frankfurter's statement made at Court conference that in the 1940s he would have found 'segregation in the schools . . . constitutional because "public opinion had not then crystallized against it"').

41. See Dotan, Yoav and Menachem Hofnung. 'Legal Defeats, Political Wins: Why Do Elected Representatives Go to Court?', 38 Comparative Political Studies 75 (2005).

42. See Klein, Claude. 'A New Era in Israel's Constitutional Law', 6 Israel Law Review 376 (1971).

43. Shamir, Ronen. "Landmark Cases" and the Reproduction of Legitimacy: The Case of Israel's High Court of Justice', 24(3) Law and Society Review 781, 785 (1990). (noting that 'the overwhelming majority of these petitions were removed, compromised or settled in one way or another' and that only 65 petitions reached adjudication and were published as HCJ decisions).

44. Dotan and Hofnung, supra note 41 at 85 .

45. See Shamir, supra note 43 , at 795 .

46. See Barzilai, Gad. 'Judicial Hegemony, Polarization of Parties, and Social Change', 3 Politika 31-51 (1988); Barzilai, Gad. 'Courts as Hegemonic Institutions: The Israeli Supreme Court in a Comparative Perspective', 
at 23, in Israel: The Dynamics of Change and Continuity, edited by David Levi-Faur, Gabriel Sheffer, and David Vogel (1999).

47. See Thomas v Mowbray, (2007) 233 CLR 307. See also Lynch, Andrew. "Australia's "War on Terror" Reaches the High Court', 32 Melbourne University Law Review 1182, 1182-3 (2008) (stating that 'the importance of the decision ... is indisputable.').

48. See Kost, Timo. 'Mounir El Motassadeq - A Missed Change for Weltinnepolik?', 8 German Law Journal 443 (2007).

49. See Nohlen, Nicholas. 'Germany: The European Arrest Warrant Case', 6 International Journal of Constitutional Law 153 (2008).

50. See A and others $v$ Secretary of State for Home Affairs, [2004] UKHL 56.

51. See People's Union for Civil Liberties v Union of India, 20049 SCC 580.

52. See Hamdi v Rumsfeld, 542 US 507, 510 (2004); Rasul v Bush, 542 US 466 (2004); Rumsfeld v Padilla, 542 US 426 (2004).

53. See, e.g., Friedman, Barry. 'Mediated Popular Constitutionalism', 101 Michigan Law Review 2596 (2003) ('Specific support is driven by agreement with particular policies, it is a measure of whether a person thinks an institution is doing a good job in terms of policy output.').

54. See Easton, David A. A Systems Analysis of Political Life (1965) at 273.

55. See Gibson, James L., Gregory A. Caldeira and Vanessa A. Baird, 'On the Legitimacy of National High Courts', 92 American Political Science Review 343, 349 (1998).

56. See supra 18 .

57. See Brown, Henry S. and Biran A. Crane, Supreme Court of Canada Practice, part 1, chapter 2 (2007).

58. [1998] 2 CSR III 9-15.

59. See Heun, supra note 10 , at 161 .

60. See Vanbeg, Georg. 'Establishing Judicial Independence in West Germany: The Impact of Opinion Leadership and the Separation of Powers', 32 Comparative Policy 333, 342 (2000).

61. See supra note 21 .

62. Id. at $342-8$.

63. See Ferejohn, John E. 'Constitutional Review in the Global Context', 6 New York University Journal of Legislation \& Public Policy 49, 51 (2002).

64. Gibson et al., supra note 55, at 355 .

65. See Durr, Robert H., Andrew D. Martin and Christina Wolbrecht. 'Ideological Divergence and Public Support for the Supreme Court', 44 American Journal of Political Science 768 (2000).

66. Brzezinski, Mark F. and Leszek Garlicki. 'Judicial Review in Post-Communist Poland: The Emergence of a Rechtsstaat?', 31 Stanford Journal of International Law 13, 13 (1995).

67. See Schwartz, Herman. 'Eastern Europe's Constitutional Courts', 9 Journal of Democracy 100, 102-03 (1998)..

68. Id.

69. Gibson, James L. aand Gregory A. Calderia. 'Defenders of Democracy? Legitimacy, Popular Acceptance, and the South African Constitutional Court', 65 Journal of Policy 1, 2 (2003).

70. See Bugaric, Bojan. 'Courts as Policy-makers: Lessons from Transition', 42 Harvard International Law Journal 247, 263 (2001).

71. 5 US (1 Cranch) 137 (1803).

72. Treanor, William Michael. 'Judicial Review before Marbury', 58 Stanford Law Review 455, 541 (2005).

73. Id. at $541-2$.

74. CC decision no. 71-44DC, July 16, 1971.

75. See Starr, Kenneth W. 'The Supreme Court and Its Shrinking Docket: The Ghost of William Howard Taft', 90 Minnesota Law Review 1363, 1369 (2006).

76. Supreme Court of Canada, Bulletin of Proceeding: Special Edition (2009).

77. Oliveira, supra note 32 , at 130-31.

78. Id. at 133 table 6.

79. Trochev, Alexi. 'Less Democracy, More Courts: A Puzzle of Judicial Review in Russia', 38 Law and Society Review 513, 514 (2004).

80. See Smithey, Shannon Ishiyama and John Ishiyama. 'Judicial Activism in Post-Communist Politics', 36 Law and Society Review 719, 723 (2002).

81. See Farganis, Dion. 'Does Reasoning Matter: The Impact of Opinion Content on Supreme Court Legitimacy', available at http://papers.ssrn.com/sol3/papers.cfm?abstract_id=1434726.

82. The Supreme Court of Argentina has in recent times faced around 26,000 cases per year. See Helmke, Gretchen. 'The Logic of Strategic Defection: Judicial Decision-Making in Argentina under Dictatorship and Democracy', 96 American Political Science Review 291 (2002). The Supreme Federal Court has faced around 110,000 in the recent past. See Oliveira, supra note32, at 100.

83. See Scheppele, supra note 9, at 1772-90. 
84. See id. at $1781-2$.

85. See Staton, Jeffrey. 'Constitutional Review and the Selective Promotion of Case Results', 50 American Journal of Political Science 98 (2006); Vanberg, Georg. 'Establishing Judicial Independence in West Germany: The Impact of Opinion Leadership and the Separation of Powers', 32 Comparative Politics 333 (2000).

86. Staton is talking mostly about Mexico, and Vanberg is talking about West Germany.

87. Staton, supra note 85, at 98 ("An exhaustive search of all European and American high, constitutional or international court Websites suggests that $71 \%$ of these courts issue press releases summarizing at least some of their resolutions.').

88. See Epp, Charles R. The Rights Revolution: Lawyers, Activists, and Supreme Courts in Comparative Perspective (1998) (discussing the existence of a 'support structure' as crucial to the judicial development and protection of individual rights in Canada, India and the United States).

89. Southworth, Ann. 'The Rights Revolution and Support Structures for Rights Advocacy', 34 Law \& Society Review 1203 (2000) (reviewing Epp, supra note 88).

90. See Wilson, Bruce M. 'Institutional Reform and Rights Revolutions in Latin America: The Cases of Costa Rica and Colombia', 2 Journal of Policy in Latin America 59, 66 (2009).

91. Tushnet, Mark. 'Social Welfare Rights and the Forms of Judicial Review', 82 Texas Law Review 1895, 1898 (2004).

92. Art. 45, Constitution of Ireland, 1937.

93. Art. 45, § 1, Constitution of Ireland, 1937.

94. Tushnet, supra note 91 , at 1902.

95. South African Constitution, § 26(2).

96. Mexico Constitution, Art. 123.

97. See Whittington, Keith. 'Interpose Your Friendly Hand: Political Supports for the Exercise of Judicial Review by the United States Supreme Court', 99 American Political Science Review 583 (2003).

98. See Dotan and Hofnung, supra note 41.

99. See supra 00 .

100. Scheppele, supra note 9, at 1770.

101. Id. at $1770-71$ n. 32.

102. See Staton, Jeffrey K. and Georg Vanbeg. 'The Value of Vagueness: Delegation, Defiance and Judicial Opinions', 51 American Journal of Political Science 504, 515 (2008).

103. Dotan an Hofnung, supra note 41, at 98.

104. See Levinson, Sanford. 'Strategy, Jurisprudence and Certiorari', 79 Virginia Law Review 717, 717-18 (1993) (reviewing H.W. Perry, Jr., Deciding to Decide: Agenda Setting in the United States Supreme Court).

105. Shamir, supra note 43 , at $795-96$.

106. See Hausmaninger, Herbert. 'Towards a "New" Russian Constitutional Court', 28 Cornell Journal of International Law 349, 350 (1995).

107. Id. at 354 .

108. Id.

109. Id.

110. Id. passim

111. Id. at 354 .

112. Id.

113. Epstein, Knight \& Shvetsova, supra note 5, at 144

114. See Hausmaninger, supra note 106 , at 366 .

115. See Law on the Constitutional Court of the RSFSR, Vedomosti RSFSR, Issue No. 30, Item No. 1017 (1991), translated in FBIS-USR-91-029, September 10, 1991, at 69, p. 14.

116. See Constitutional Law on the Constitutional Court, SZ RF Issue No. 13, Item No. 1447 (1994), translated in FBIS-SOV-94-145-S, July 28, 1994, ch. XII.

117. See Epstein et al., supra note 5, at 122 n.6.

118. Id. See also Scheppele, supra note 99, at 1769 n. 29 ('In practice, because of the huge press of cases, however, courts have to find a way to triage their decisions. The Russian Constitutional Court separates cases into first impression cases (postanovlenia) versus mere elaborations (opredelenia). Postanovlenia require formal briefing, oral arguments, and plenary sessions of a senate of the court. Opredelenia are decided on the basis of the initial submissions and are generally written by one judge as rapporteur, with the decision then voted on in a full plenary session of the Court, without full oral argument.').

119. US Constitution art. II, $\S 2$ ('The President ... by and with the Advice and Consent of the Senate, shall appoint ... Judges of the supreme Court, and all other Officers of the United States.').

120. France Constitution art. 56.

121. See Epstein, Lee, Jeffrey A. Segal, Harold G. Spaeth and Thomas G. Walker, The Supreme Court Compendium: Data, Decisions, and Developments 71-6 table 2-2 (2nd edition, 1996). 
122. See Oliveira, supra note $32,100$.

123. See Rogers, James R. 'Information and Judicial Review: A Signaling Game of Legislative-Judicial Interaction', 45 American Journal of Political Science 84 (2001).

124. See Gunther, Gerald. 'The Subtle Vices of the "Passive Virtues" - A Comment on Principle and Expediency in Judicial Review', 64 Columbia Law Review 1 (1964).

125. Id. at 24-5.

126. See Sager, Lawrence Gene. 'Fair Measure: The Legal Status of Underenforced Constitutional Norms', 91 Harvard Law Review 1212 (1978).

127. The failures of the Tribunal of Constitutional Guarantees of Costa Rica to decide major cases, and the damage it did to that court, are good examples of this dynamic. See Dargent, Eduardo. 'Determinants of Judicial Independence: Lessons from Three "Cases" of Constitutional Courts in Peru (1982-2007)', 41 Journal of Latin American Studies 251, $263-4$ (2009).

128. See, e.g., Khadr v Canada (Prime Minister), [2009] FCJ No. 893 (CA); Canada (Attorney General) v Ribic, [2005] 1 FCR 33 (FCR 2003); Canadian Security Intelligence Service Act (Can.) (Re), [2009] FCJ No. 1153 (FCC 2009); Almrei (Re), [2009] FCJ No. 1 (FCC 2009);Amnesty International Canada v Canada (Canadian Forces), [2008] FCJ No. 356 (FCC 2008). 
